Article

\title{
Co-Stimulation of Purinergic P2X4 and Prostanoid EP3 Receptors Triggers Synergistic Degranulation in Murine Mast Cells
}

\author{
Kazuki Yoshida ${ }^{1}$, Makoto Tajima ${ }^{1}$, Tomoki Nagano ${ }^{1}$, Kosuke Obayashi ${ }^{1}$, Masaaki Ito ${ }^{1}$, \\ Kimiko Yamamoto ${ }^{2}$ and Isao Matsuoka ${ }^{1, *}$ \\ 1 Laboratory of Pharmacology, Faculty of Pharmacy, Takasaki University of Health and Welfare, Takasaki-shi, \\ Gunma 370-0033, Japan; yoshida-k@takasaki-u.ac.jp (K.Y.); 1321057@takasaki-u.ac.jp (M.T.); \\ 1321067@takasaki-u.ac.jp (T.N.); 0821024@takasaki-u.ac.jp (K.O.); mito@takasaki-u.ac.jp (M.I.) \\ 2 Department of Biomedical Engineering, Graduate School of Medicine, The University of Tokyo, \\ Tokyo 113-0033, Japan; k-yamamoto@umin.ac.jp \\ * Correspondence: isao@takasaki-u.ac.jp; Tel.: +81-27-352-1180
}

Received: 4 October 2019; Accepted: 16 October 2019; Published: 17 October 2019

\begin{abstract}
Mast cells (MCs) recognize antigens (Ag) via IgE-bound high affinity IgE receptors (FceRI) and trigger type I allergic reactions. FceRI-mediated MC activation is regulated by various $\mathrm{G}$ protein-coupled receptor (GPCR) agonists. We recently reported that ionotropic P2X4 receptor (P2X4R) stimulation enhanced FceRI-mediated degranulation. Since MCs are involved in Ag-independent hypersensitivity, we investigated whether co-stimulation with ATP and GPCR agonists in the absence of $\mathrm{Ag}$ affects $\mathrm{MC}$ degranulation. Prostaglandin $\mathrm{E}_{2}\left(\mathrm{PGE}_{2}\right)$ induced synergistic degranulation when bone marrow-derived MCs (BMMCs) were co-stimulated with ATP, while pharmacological analyses revealed that the effects of $\mathrm{PGE}_{2}$ and ATP were mediated by EP3 and P2X4R, respectively. Consistently, this response was absent in BMMCs prepared from P2X4R-deficient mice. The effects of ATP and $\mathrm{PGE}_{2}$ were reduced by PI3 kinase inhibitors but were insensitive to tyrosine kinase inhibitors which suppressed the enhanced degranulation induced by Ag and ATP. MC-dependent PGE $_{2}$-triggered vascular hyperpermeability was abrogated in a P2X4R-deficient mouse ear edema model. Collectively, our results suggest that P2X4R signaling enhances EP3R-mediated MC activation via a different mechanism to that involved in enhancing Ag-induced responses. Moreover, the cooperative effects of the common inflammatory mediators ATP and $\mathrm{PGE}_{2}$ on MCs may be involved in Ag-independent hypersensitivity in vivo.
\end{abstract}

Keywords: extracellular ATP; P2X4 receptor; prostaglandin $\mathrm{E}_{2}$; EP3 receptor; bone marrow-derived mast cell; mast cell degranulation; $\mathrm{Ca}^{2+}$ influx; PI3 kinase

\section{Introduction}

Mast cells (MC) are widely distributed in the body and abundant in tissues that contact with the external environment, such as the intestine, respiratory tract, and skin [1]. MCs are replete with secretory granules containing a variety of preformed mediators, such as histamine, cytokines, and proteases, that they release in response to various harmful pathogens or invading external substances [2]. This process is thought to initiate immunoregulatory reactions by providing a microenvironment that recruits and activates other immunocompetent cells; however, such reactions are sometimes inappropriately enhanced under certain conditions, causing hypersensitivity and allergic inflammation [3]. The most well-known MC activation pathway involves high affinity IgE receptors (FceRI), which enable MCs to form a barrier against pathogen invasion [4]. When antigens (Ag) cross-link the IgE-FceRI complex, many signaling molecules are phosphorylated by the protein tyrosine 
kinase Lyn and subsequently recruited Syk, activating multiple pathways involving processes such as degranulation, cytokine production, and lipid mediator production [5]. MCs are known to express various immunoregulatory receptors, including toll-like receptors, stem cell factor (SCF) receptors, and G-protein-coupled receptors (GPCR), whose stimulation has been reported to promote IgE-dependent MC degranulation [6]. For instance, it has been shown that $\mathrm{PGE}_{2}$, which is known to mediate inflammation [7], and adenosine, which accumulates extracellularly under ischemic conditions [8], enhance Ag-mediated MC degranulation [9-11]. The effects of $\mathrm{PGE}_{2}$ and adenosine are mediated by the EP3 receptor (EP3R) and $A_{3}$ receptor $\left(A_{3} R\right)$, respectively, and are commonly transmitted via the pertussis toxin (PTX)-sensitive Gi protein, suggesting a similar underlying mechanism. Indeed, several studies have demonstrated that enhancing Ag-induced MC degranulation by co-stimulation with Gi-coupled receptor agonists requires the activation of phosphoinositide 3-kinase (PI3K) $\gamma$, a PI3K subclass regulated by the Gi protein $\beta \gamma$ subunit $[10,11]$. These enhanced responses are thought to be involved in exacerbating allergic reactions.

In addition to Gi-coupled receptor agonists, we recently reported that extracellular ATP also enhances the Ag-induced degranulation response in bone marrow-derived MCs (BMMCs) by activating the P2X4 receptor (P2X4R), a ligand-gated ion channel [12]. Unlike Gi-coupled receptor agonists, P2X4R stimulation does not induce the PI3K signaling pathway, but enhances the Ag-induced tyrosine phosphorylation of signaling molecules including Syk and phospholipase C (PLC) $\gamma$ [13]. Based on these results, we hypothesized that stimulation of MCs with ATP and Gi-coupled receptor agonists may cause MC degranulation in an IgE-independent manner. Indeed, we previously showed that co-stimulating BMMCs with ATP and adenosine induced synergistic degranulation via $A_{3} R$ [12].

With respect to IgE-independent MC activation, MCs express several pattern recognition-receptors, such as toll-like receptor 2 and 4, which are stimulated by micro-organism specific molecular motif, triggering the innate immune responses [14]. In this category, extracellular ATP is also considered to act as a danger signal, because living cells contain high concentrations of ATP and release it to extracellular space under adverse conditions, like tissue damage, necrosis, and pyroptosis [15]. The accumulation of ATP is detected by surrounding cells through a wide variety of receptors; not

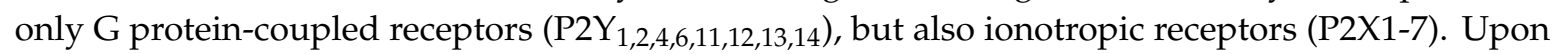
stimulation through different mechanism, $\mathrm{MC}$ is known to be capable of producing a wide variety of inflammatory and anti-inflammatory cytokines, no less than other immune cells such as macrophages and lymphocytes [16]. Indeed, MCs have quite recently been implicated in the pathogenesis of systemic lupus erythematosus [17] and neurofibromatosis [18]. In such inflammatory diseases, MC activation cannot be explained only by the IgE-dependent mechanism. Since, extracellular ATP is suggested to be released from cells via mechanical stress such as itching-induced scratching behavior $[19,20]$, MCs must be exposed to ATP and various humoral factors in the inflammatory environment.

This study therefore investigated whether combining ATP with GPCR agonists affected MC degranulation, finding that co-stimulation with ATP and $\mathrm{PGE}_{2}$ induced synergistic $\mathrm{MC}$ degranulation by activating P2X4 and EP3R, respectively, via a novel mechanism that is different to the Ag-induced response.

\section{Results}

\subsection{Effects of ATP and GPCR Agonist co-Stimulation on BMMC Degranulation}

We first examined the effect of ATP and GPCR agonist co-stimulation on the degranulation of BMMCs. We tested the GPCR agonists sphingosine-1-phosphate (S1P) $(1 \mu \mathrm{M}), \mathrm{PGE}_{2}(1 \mu \mathrm{M})$, histamine $(100 \mu \mathrm{M}), \mathrm{C} 5 \mathrm{a}(10 \mathrm{nM}), \mathrm{PGD}_{2}(1 \mu \mathrm{M})$, UDP-glucose $(100 \mu \mathrm{M})$, and compound $48 / 80(10 \mu \mathrm{M})$, all of which constantly increased the intracellular $\mathrm{Ca}^{2+}$ concentration $\left(\left[\mathrm{Ca}^{2+}\right] \mathrm{i}\right)$ of Fura-2 loaded BMMCs, albeit to varying degrees (data not shown). Although these GPCR agonists had no effect on BMMC degranulation when tested alone, $\mathrm{PGE}_{2}$ markedly induced degranulation when concurrently stimulated with $100 \mu \mathrm{M}$ ATP (Figure 1A). Time course experiments revealed that co-stimulation with ATP and 
$\mathrm{PGE}_{2}$ induced degranulation rapidly, with the response initiated within 2 min and reaching the maximum steady state in 5 min (Figure 1B). Different $\mathrm{PGE}_{2}$ concentrations only induced BMMC degranulation in a concentration-dependent manner in the presence of $100 \mu \mathrm{M}$ ATP, with PGE $_{1}$ inducing similar effects (Figure 1C). Moreover, the effects of ATP on degranulation in the presence of $\mathrm{PGE}_{2}$ were concentration-dependent (Figure 1D). On the basis of these results, we examined the effects of co-stimulation with $100 \mu \mathrm{M}$ ATP and $1 \mu \mathrm{M} \mathrm{PGE}_{2}$ for $5 \mathrm{~min}$ in the following experiments.

A

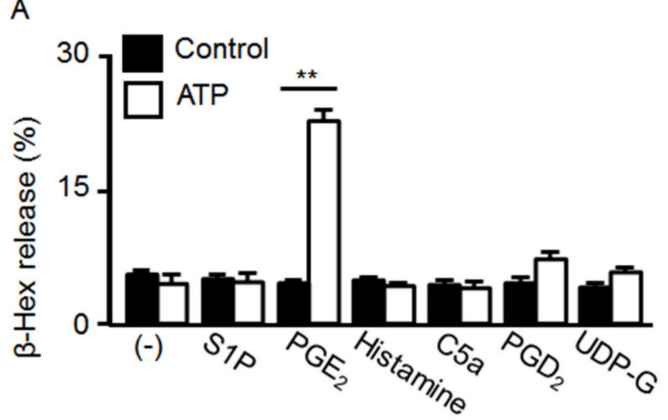

C

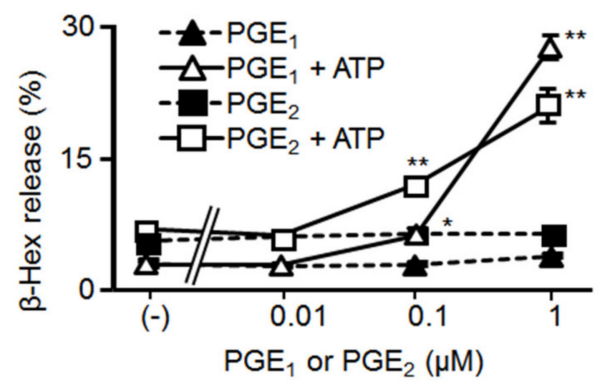

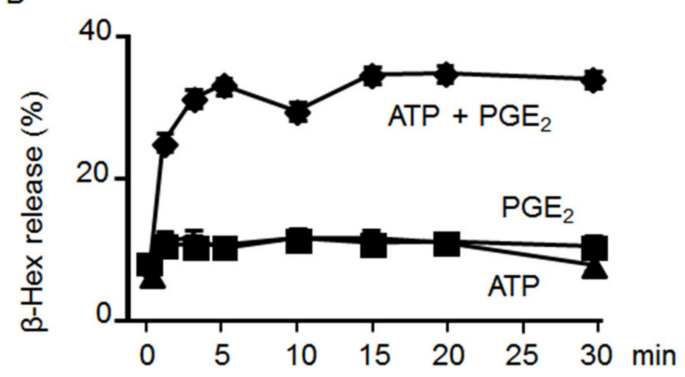

D

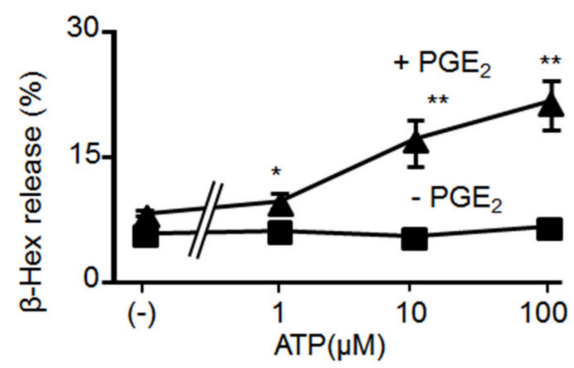

Figure 1. Synergistic effects of ATP and prostaglandin (PG) $\mathrm{E}_{2}$ on mast cell (MC) degranulation. (A) Bone marrow-derived MCs (BMMCs) were stimulated with sphingosine-1-phosphate (S1P) $(1 \mu \mathrm{M}), \mathrm{PGE}_{2}$ $(1 \mu \mathrm{M})$, histamine $(100 \mu \mathrm{M}), \mathrm{C} 5 \mathrm{a}(10 \mathrm{nM}), \mathrm{PGD}_{2}(1 \mu \mathrm{M})$, and UDP-glucose $(100 \mu \mathrm{M})$ with or without ATP $(100 \mu \mathrm{M})\left(n=3\right.$, mean \pm SEM). ${ }^{* *} p<0.01$ indicates a significant difference from the control. (B) BMMCs were stimulated for 1-30 min with ATP $(100 \mu \mathrm{M}, \mathbf{\Lambda})$ and PGE $2(1 \mu \mathrm{M}, \boldsymbol{\square})$ alone or simultaneously ( $n=3$, mean \pm SEM). (C) BMMCs were stimulated with different concentrations $(0.01-1 \mu \mathrm{M})$ of PGE $1(\Delta$, $\Delta)$ and $\operatorname{PGE}_{2}(\square, \boldsymbol{\square})$ with $(\triangle, \square)$ or without $(\boldsymbol{\Lambda}, \mathbf{\square}) \operatorname{ATP}(100 \mu \mathrm{M})(n=3$, mean \pm SEM $) .{ }^{*} p<0.05$ and ${ }^{* *} p<0.01$ indicate significant differences compared to ATP alone. (D) BMMCs were stimulated with different concentrations of ATP $(1-100 \mu \mathrm{M})$ with $(\boldsymbol{\Delta})$ or without $(\boldsymbol{\square}) \mathrm{PGE}_{2}(1 \mu \mathrm{M})(n=3$, mean \pm SEM). ${ }^{*} p<0.05$ and ${ }^{* *} p<0.01$ indicate significant differences compared to $\mathrm{PGE}_{2}$ alone.

\subsection{Involvement of Gi-Coupled EP3R in Synergistic Degranulation Induced by $P G E_{2}$ and ATP}

The biological effects of $\mathrm{PGE}_{2}$ are known to be mediated by four different EP receptors. Quantitative reverse transcription-polymerase chain reaction (qRT-PCR) revealed that the BMMCs used in this study expressed EP1, EP3, and EP4 receptor mRNAs, while pharmacological experiments with selective EPR antagonists revealed that only the EP3 antagonist ONO-AE3-208 inhibited the degranulation induced by $\mathrm{PGE}_{2}$ and ATP (Figure 2A). Consistently, only the ONO-AE-248 agonist against EP3R, a Gi-coupled receptor, induced degranulation in the presence of ATP (Figure 2B). Moreover, the degranulation induced by $\mathrm{PGE}_{2}$ and ATP was abolished by pretreating the BMMCs with $50 \mathrm{ng} / \mathrm{mL}$ of PTX (Figure 2C). 
A

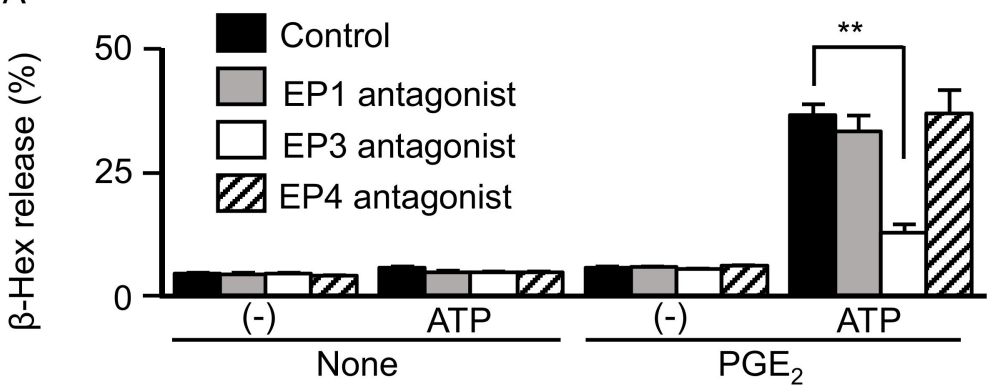

B

$\square \mathrm{PGE}_{2} \square \mathrm{EP} 1$ agonist

C
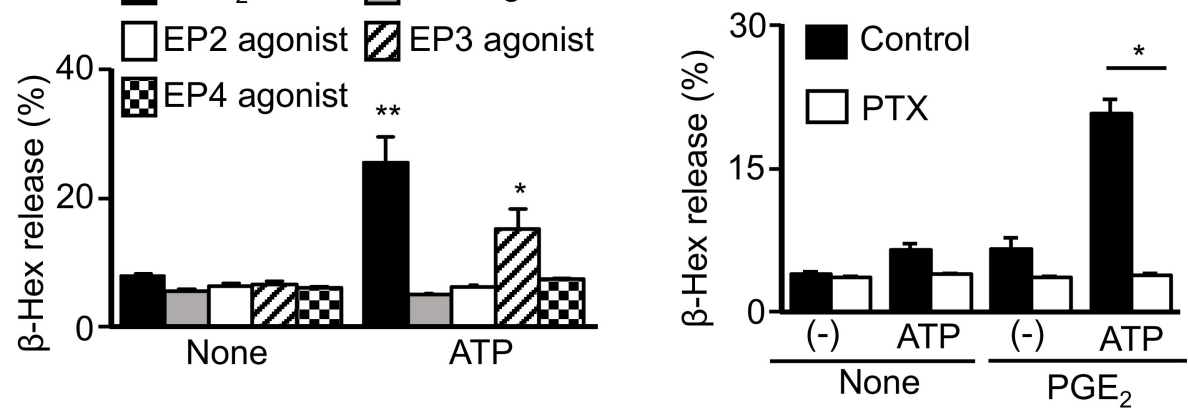

Figure 2. Involvement of EP3 receptor activation in the synergistic effect of prostaglandin (PG) $\mathrm{E}_{2}$ and ATP on mast cell (MC) degranulation. (A) Bone marrow-derived MCs were preincubated with a vehicle, ONO-8713 (EP1 antagonist), ONO-AE3-240 (EP3 antagonist), and ONO-AE3-208 (EP4 antagonist) at $1 \mu \mathrm{M}$ for $5 \mathrm{~min}$ and then stimulated with vehicle (-) or ATP $(100 \mu \mathrm{M})$ with or without $\mathrm{PGE}_{2}(1 \mu \mathrm{M})$ for $5 \mathrm{~min}$. Data are shown as the mean $\pm \operatorname{SEM}(n=3) .{ }^{*} p<0.05$ indicates a significant difference from the control. (B) BMMCs were stimulated with PGE 2 , ONO-DI-004 (EP1 agonist), ONO-AE1-259 (EP2 agonist), ONO-AE-248 (EP3 agonist), or ONO-AE1-329 (EP4 agonist) at $1 \mu \mathrm{M}$ with or without ATP $(100 \mu \mathrm{M})$. Data are shown as the mean $\pm \operatorname{SEM}(n=3) .{ }^{*} p<0.05$ and ${ }^{* *} p<0.01$ indicate significant differences from the response without ATP (none). (C) BMMCs were treated with or without pertussis toxin (PTX, $50 \mathrm{ng} / \mathrm{mL})$ overnight and stimulated with ATP $(100 \mu \mathrm{M})$ with or without $\mathrm{PGE}_{2}(1 \mu \mathrm{M})$ for $5 \mathrm{~min}$. Data are shown as the mean $\pm \operatorname{SEM}(n=3) .{ }^{*} p<0.05$ indicates a significant difference from the control.

\subsection{Involvement of Ionotropic P2X4R in the Effect of ATP and PGE 2 on Degranulation}

We next attempted to identify the P2 receptor subtype that mediates the effect of ATP on degranulation with $\mathrm{PGE}_{2}$. We previously reported that under our experimental conditions, BMMCs express ionotropic $\mathrm{P} 2 \mathrm{X} 1,4$, and 7, which are all stimulated by ATP, and $\mathrm{G}$ protein-coupled $\mathrm{P} 2 \mathrm{Y}_{1,2}$, and 14 receptors, which are stimulated by ADP, UTP, and UDP-glucose, respectively [21]. Since UDP-glucose had little effect (Figure 1A), we examined the effects of ADP and UTP on degranulation with PGE $_{2}$. As shown in Figure 3A, ADP and UTP had weak effects on degranulation with $\mathrm{PGE}_{2}$ compared to ATP. Consistently, the effect of ATP on degranulation with $\mathrm{PGE}_{2}$ was not affected by the P2Y antagonist MRS2179 or $\mathrm{P}_{2} \mathrm{Y}_{2}$ antagonist AR-C118925 (Figure 3B). Among the P2X receptor antagonists, degranulation induced by ATP and $\mathrm{PGE}_{2}$ was inhibited by the P2X4 antagonist 5-BDBD, but not the P2X1 antagonist NF449 or P2X7 antagonist AZ10606120 (Figure 3C,D). Furthermore, the effect of ATP on degranulation with $\mathrm{PGE}_{2}$ was enhanced by the $\mathrm{P} 2 \mathrm{X} 4 \mathrm{R}$ positive allosteric modulator ivermectin (Figure 3D) but totally absent in BMMCs prepared from P2X4R-deficient mice (Figure 3E). 


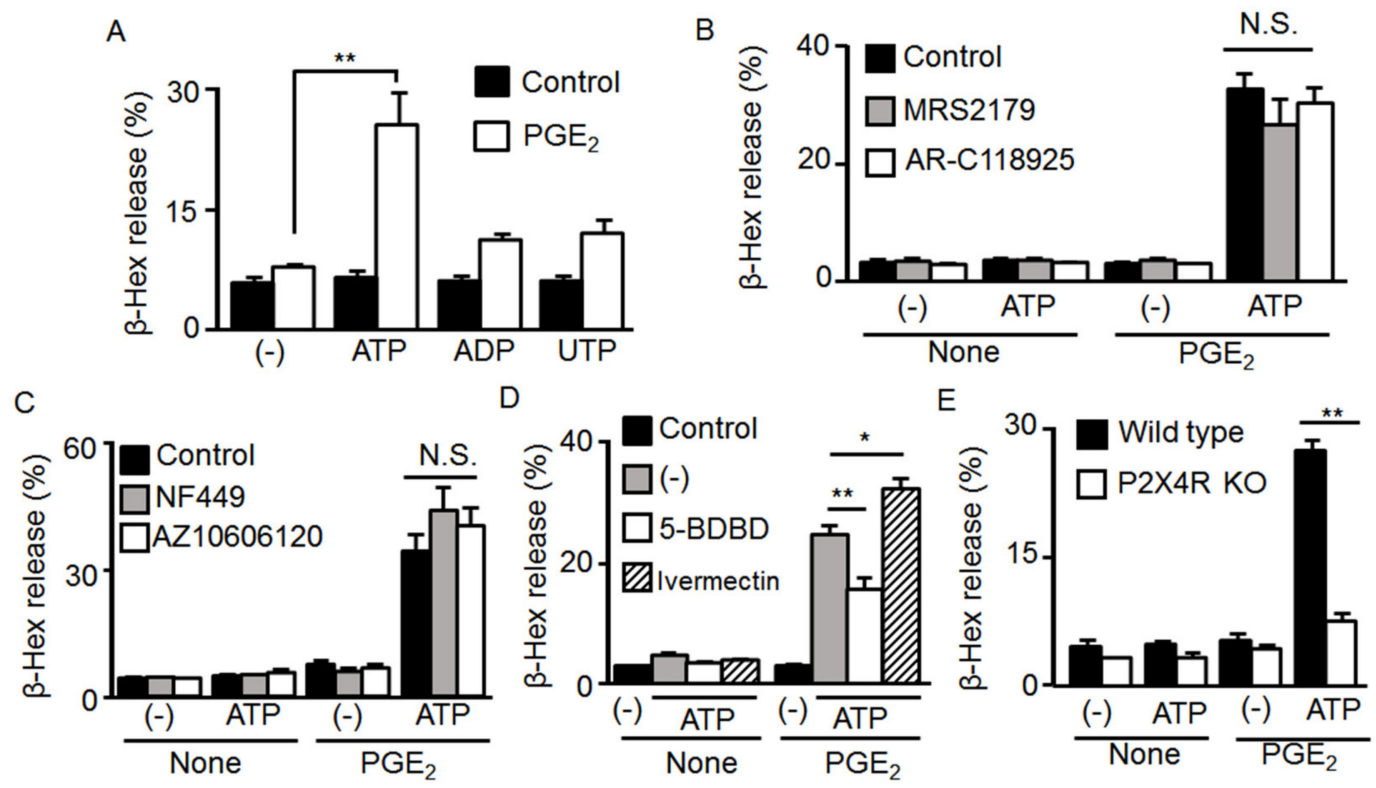

Figure 3. Involvement of $\mathrm{P} 2 \mathrm{X} 4$ receptor (P2X4R) activation in the synergistic effect of prostaglandin (PG) $\mathrm{E}_{2}$ and ATP on mast cell (MC) degranulation. (A) Bone marrow-derived MCs (BMMCs) were stimulated concurrently with $\mathrm{PGE}_{2}(1 \mu \mathrm{M})$ and a vehicle, ATP, ADP, or UTP $(100 \mu \mathrm{M})$ for 5 min. (B) BMMCs were preincubated with a vehicle, the P2 $\mathrm{Y}_{1}$ antagonist MRS2179 $(10 \mu \mathrm{M})$, or the P2Y 2 antagonist AR-C118925 $(10 \mu \mathrm{M})$ for $5 \mathrm{~min}$ and then stimulated with ATP $(100 \mu \mathrm{M})$ with or without $\mathrm{PGE}_{2}(1 \mu \mathrm{M})$ for $5 \mathrm{~min}$. (C) BMMCs were preincubated with a vehicle, the P2X1 antagonist NF449 $(10 \mu \mathrm{M})$, or the P2X7 antagonist AZ10606120 $(1 \mu \mathrm{M})$ for 3 min and then stimulated with ATP (100 $\mu \mathrm{M})$ with or without $\mathrm{PGE}_{2}(1 \mu \mathrm{M})$ for $5 \mathrm{~min}$. (D) BMMCs were preincubated with a vehicle, the P2X4 antagonist 5-BDBD $(10 \mu \mathrm{M})$, or the P2X4R positive allosteric modulator ivermectin $(10 \mu \mathrm{g} / \mathrm{mL})$ for 5 min and then stimulated with ATP $(100 \mu \mathrm{M})$ with or without $\mathrm{PGE}_{2}(1 \mu \mathrm{M})$ for $5 \mathrm{~min}$. (E) BMMCs prepared from wild type and P2X4R-deficient mice (P2X4R KO) were stimulated with ATP $(100 \mu \mathrm{M})$ with or without $\mathrm{PGE}_{2}(1 \mu \mathrm{M})$ for $5 \mathrm{~min}$. Data are shown as the mean $\pm \mathrm{SEM}(n=3)$. N.S. no significant difference, ${ }^{*} p<0.05$ and ${ }^{* *} p<0.01$ indicate significant differences.

\subsection{Mechanism underlying the Synergistic Degranulation Induced by ATP and $P G E_{2}$}

We recently reported that stimulating P2X4R enhanced Ag-induced degranulation and increased Src tyrosine kinase signaling pathways, such as Syk and phospholipase $\mathrm{C} \gamma$ (MS submitted). Therefore, we examined effects of the Src family tyrosine kinase inhibitor PP2 and the Syk inhibitor R406 on degranulation induced by ATP and PGE 2 . As shown in Figure 4A,B, although both PP2 and R406 effectively inhibited the degranulation induced by co-stimulation with ATP and Ag, they had little effect on that induced by ATP and $\mathrm{PGE}_{2}$. It has been reported that MC degranulation induced by $\mathrm{PGE}_{2}$ is mediated by PI3K [10]. Consistent with the previous report, MC degranulation induced by co-stimulation with ATP and $\mathrm{PGE}_{2}$ was inhibited by the non-selective PI3 kinase inhibitor LY294002 but not the structurally similar negative control LY303511 (Figure 4C). The response was also inhibited by AS605240, a specific PI3K $\gamma$ inhibitor that is activated by G protein $\beta \gamma$ subunits (Figure 4D), whereas the Akt inhibitor triciribine had no effect on the degranulation induced by ATP and $\mathrm{PGE}_{2}$ (Figure 4E). These results suggest that P2X4R stimulation enhanced EP3R-mediated signaling in a PI3K-dependent but Akt-independent manner. 
A B

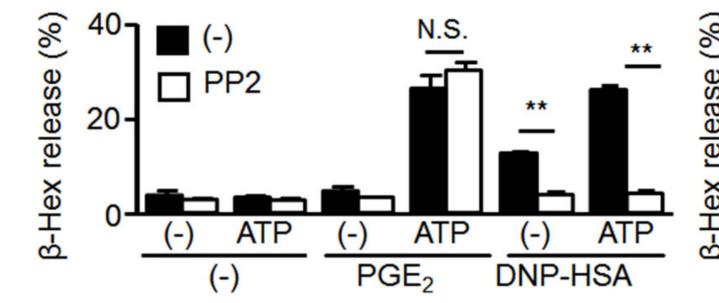

C
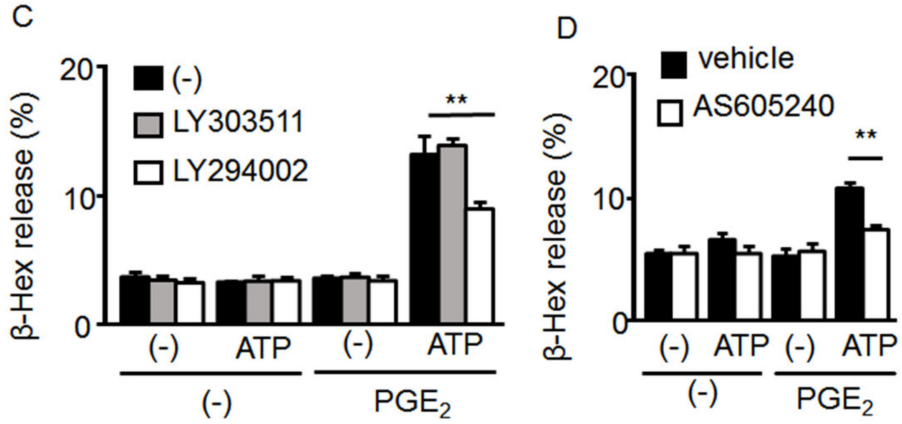

E

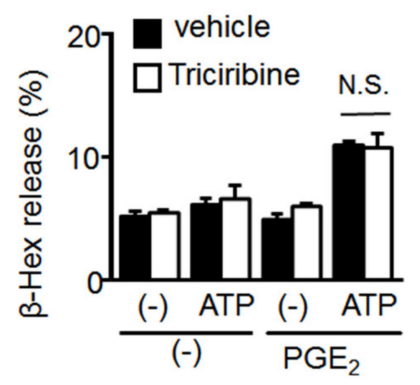

Figure 4. Effect of tyrosine kinase and phosphoinositide 3-kinase (PI3K)/Akt signaling pathway inhibitors on mast cell (MC) degranulation induced by co-stimulation with ATP and prostaglandin $(\mathrm{PG}) \mathrm{E}_{2}$. (A) Bone marrow-derived MCs (BMMCs) were preincubated with a vehicle or the Src tyrosine kinase inhibitor PP2 $(1 \mu \mathrm{M})$ for $5 \mathrm{~min}$ and then stimulated with ATP $(100 \mu \mathrm{M})$ with or without $\mathrm{PGE}_{2}(1 \mu \mathrm{M})$ or 2,4-dinitrophenyl human serum albumin (DNP-HSA, $10 \mathrm{ng} / \mathrm{mL}$ ). (B) BMMCs were preincubated with a vehicle or the Syk inhibitor R406 $(2 \mu \mathrm{M})$ for $5 \mathrm{~min}$ and then stimulated with ATP $(100 \mu \mathrm{M})$ with or without $\mathrm{PGE}_{2}(1 \mu \mathrm{M})(n=3)$. (C) BMMCs were preincubated with a vehicle, the PI3K inhibitor LY294002 $(10 \mu \mathrm{M})$, or the control compound LY303511 $(10 \mu \mathrm{M})$ for $5 \mathrm{~min}$ and then stimulated with ATP $(0.1 \mathrm{mM})$ with or without $\mathrm{PGE}_{2}(1 \mu \mathrm{M})(n=3)$. (D) BMMCs were preincubated with a vehicle or the PI3K $\gamma$ inhibitor AS605240 $(1 \mu \mathrm{M})$ for $5 \mathrm{~min}$ and then stimulated with ATP $(100 \mu \mathrm{M})$ with or without $\mathrm{PGE}_{2}(1 \mu \mathrm{M})(n=3)$. (E) BMMCs were preincubated with a vehicle or the Akt inhibitor triciribin $(10 \mu \mathrm{M})$ for $5 \mathrm{~min}$, and then stimulated with ATP $(100 \mu \mathrm{M})$ with or without PGE $_{2}(1 \mu \mathrm{M})$ $(n=3)$. Data are shown as the mean \pm SEM. N.S. no significant difference, ${ }^{* *} p<0.01$ indicates a significant difference.

\subsection{Effects of Co-Stimulating BMMCs with ATP and PGE 2 on ERK1/2, Akt, and Syk Phosphorylation}

As shown previously, ATP enhanced Ag-induced Syk phosphorylation (Figure 5A) in BMMCs; however, neither $\mathrm{PGE}_{2}$ nor co-stimulation with $\mathrm{PGE}_{2}$ and ATP affected Syk phosphorylation (Figure 5A). In contrast, stimulation with $\mathrm{PGE}_{2}$ and ATP alone induced ERK1/2 and Akt phosphorylation in a time-dependent manner. Furthermore, Syk phosphorylation in response to ATP and Ag was greater than the response to either alone, whereas the Akt and ERK1/2 phosphorylation induced by co-stimulation with ATP and PGE 2 was slightly lower (Figure 5B). 

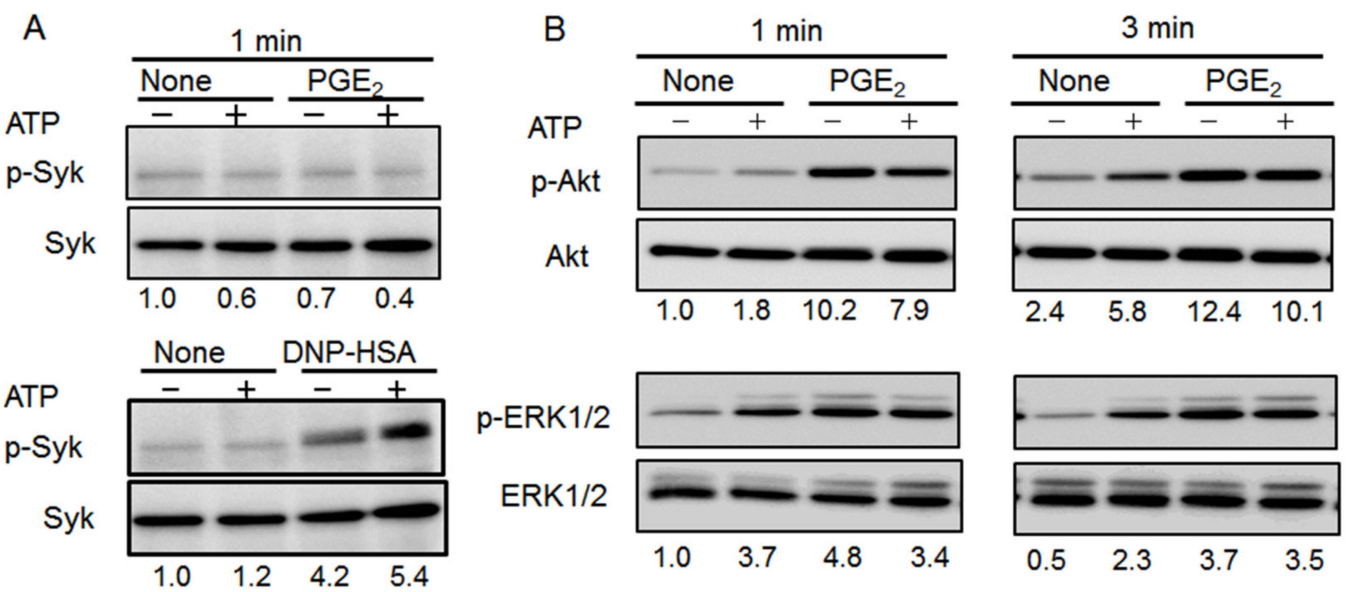

Figure 5. Effect of co-stimulation with ATP and prostaglandin (PG) $\mathrm{E}_{2}$ on Syk, extracellular signal-regulated kinase (ERK)1/2, and Akt phosphorylation in bone marrow-derived mast cells (BMMCs). (A) BMMCs were stimulated with ATP $(100 \mu \mathrm{M})$ with or without $\mathrm{PGE}_{2}(1 \mu \mathrm{M}$, upper) or 2,4-dinitrophenyl human serum albumin (DNP-HAS,10 ng/mL, lower) for $1 \mathrm{~min}$. Cell lysates were subjected to western blot analysis for phospho-Syk and total-Syk. (B) BMMCs were stimulated with ATP $(100 \mu \mathrm{M})$ with or without PGE $2(1 \mu \mathrm{M})$ for 1 (left) or 3 (right) min. Cell lysates were subjected to western blot analysis for phospho-Akt and total Akt (upper) or phospho-ERK 1/2 and total-ERK 1/2 (lower). The numbers below each image indicate normalized relative phosphorylated protein intensity; the results for no stimulation are set to one. Blots are representative of three independent experiments.

\subsection{Effects of Co-Stimulating BMMCs with ATP and $P G E_{2}$ on $\left[\mathrm{Ca}^{2+}\right] i$}

In Fura-2-loaded BMMCs, ATP stimulation induced a rapid increase in $\left[\mathrm{Ca}^{2+}\right] \mathrm{i}$ which decreased to a sustained steady state, whereas $\mathrm{PGE}_{2}$ induced a similar $\left[\mathrm{Ca}^{2+}\right]$ increase, but to a weaker extent than that induced by ATP. Co-stimulation with ATP and $\mathrm{PGE}_{2}$ resulted in a sustained increase in $\left[\mathrm{Ca}^{2+}\right] \mathrm{i}$ that was greater than the additive responses elicited by ATP or $\mathrm{PGE}_{2}$ alone, but was not evident in BMMCs obtained from P2X4-deficient mice (Figure 6A,B), and was inhibited by the PI3K $\gamma$ inhibitor AS605240 (Figure 6C,D). 

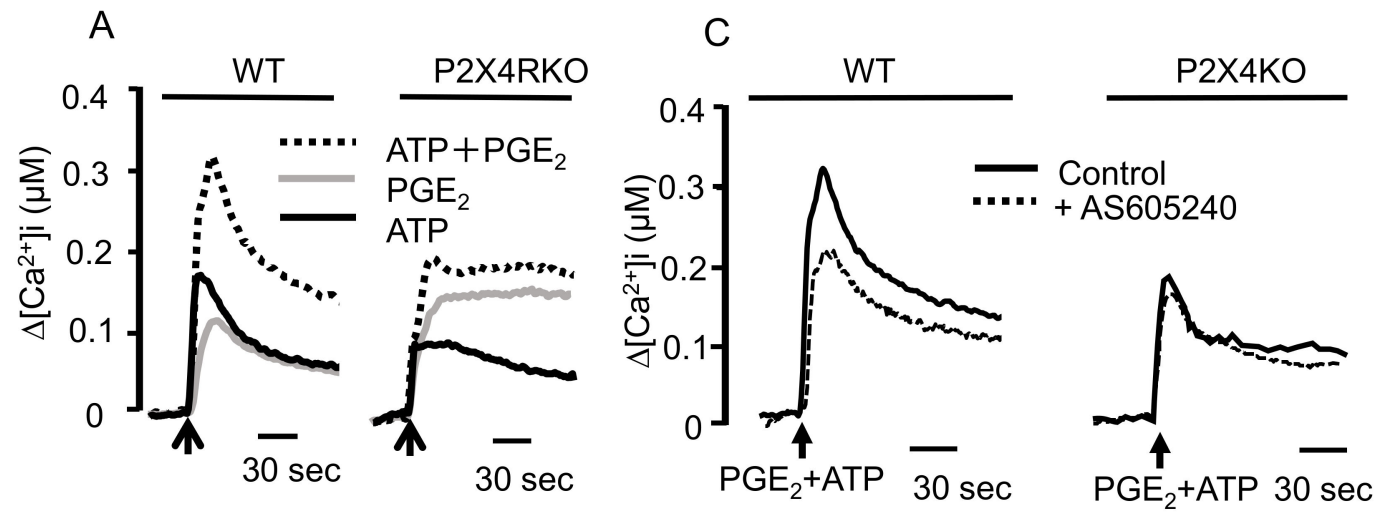

$\mathrm{B}$
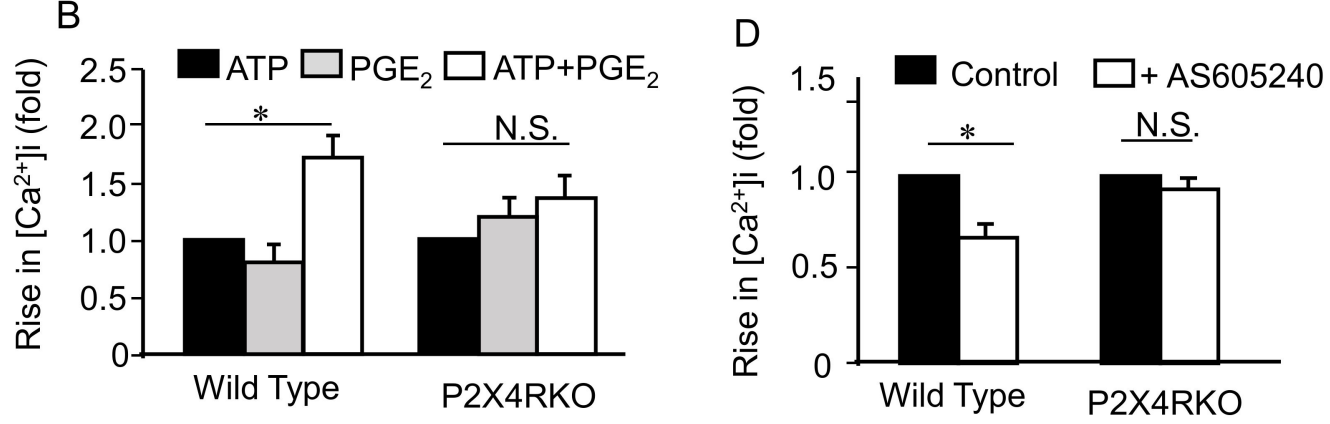

Figure 6. Effects of co-stimulating bone marrow-derived mast cells (BMMCs) with ATP and prostaglandin $(\mathrm{PG}) \mathrm{E}_{2}$ on intracellular $\mathrm{Ca}^{2+}$ concentration $\left(\left[\mathrm{Ca}^{2+}\right] \mathrm{i}\right)$ levels. (A) BMMCs prepared from widg type (WT) or P2X4 receptor deficient (P2X4RKO) mice were loaded with Fura-2 acetoxymethyl ester and changes in $\left[\mathrm{Ca}^{2+}\right]$ i were monitored after stimulating with ATP (black line), $\mathrm{PGE}_{2}$ (gray line), or ATP plus $\mathrm{PGE}_{2}$ (dotted line) at the time indicated by the arrow. The $\mathrm{Ca}^{2+}$ data are representative of four independent experiments. (B)Summary of the data obtained in A. Results are indicated as fold of ATP-induced response (WT; $205 \pm 38 \mathrm{nM}, n=4$, P2X4RKO; $115 \pm 16 \mathrm{nM}, n=4$ ). Data are shown as the mean $\pm \operatorname{SEM}(n=4)$. N.S.; no significant difference, ${ }^{*} p<0.05$ indicates a significant difference. (C) BMMCs prepared from WT or P2X4RKO were preincubated with or without the PI3K $\gamma$ inhibitor AS605240 $(1 \mu \mathrm{M})$ for 5 min and then stimulated with ATP $(100 \mu \mathrm{M})$ plus PGE $2(1 \mu \mathrm{M})$. The superimposed $\left[\mathrm{Ca}^{2+}\right]$ i changes are representative of at least four different BMMC preparations obtained from different animals. (D) Summary of the data obtained in C. Results are indicated as fold of control response (WT; $342 \pm 45 \mathrm{nM}, n=3$, P2X4RKO; $158 \pm 29 \mathrm{nM}, n=4)$. Data are shown as the mean $\pm \operatorname{SEM}(n=3-4)$. N.S.; no significant difference, ${ }^{*} p<0.05$ indicates a significant difference.

\subsection{Role of $P 2 X 4 R$ Signaling in $P G E_{2}$-Induced Skin MC Activation in Vivo}

Administering $\mathrm{PGE}_{2}$ to mouse ears reportedly induces edema due to increased extravasation via the EP3R-mediated activation of resident MCs [22]; therefore, we examined whether P2X4R contributed toward this response. Intradermally injecting $\mathrm{PGE}_{2}$ into the auricle of wild type mice caused significant Evans blue leakage compared to solvent-injected auricles (Figure 7); however, these effects were

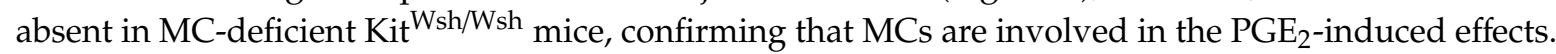
Moreover, the effect of $\mathrm{PGE}_{2}$ on dye leakage was significantly abrogated in P2X4R-deficient mice (Figure 7). 


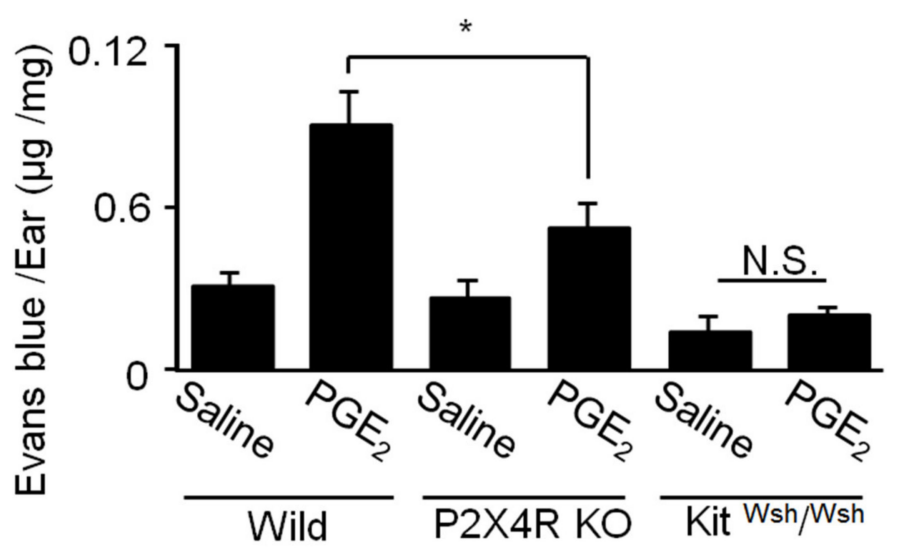

Figure 7. Comparison of prostaglandin (PG) $\mathrm{E}_{2}$-induced hyperpermeability in wild type, P2X4 receptor-deficient (P2X4RKO), and mast cell-deficient Kit Wsh/Wsh mice. PGE 2 (1.5 nmol) was intradermally injected into the ear and vascular permeability measured $30 \mathrm{~min}$ later. Data are shown as the mean $\pm \operatorname{SEM}(n=5-6)$. N.S. no significant difference, ${ }^{*} p<0.05$ indicates a significant difference.

\section{Discussion}

Previously, we reported that Ag-induced MC degranulation was enhanced by extracellular ATP [12]. Although various GPCR agonists have been shown to enhance Ag-induced degranulation, particularly those acting on Gi-coupled receptors [9,11], we found that the ATP-induced response was mediated by the ionotropic P2X4R [12]. This study examined whether P2X4R stimulation affected IgE-independent MC activation in combination with the GPCR agonists S1P, compound 48/80, UDP-glucose, C5a, histamine, $\mathrm{PGD}_{2}$, and $\mathrm{PGE}_{2}$, which reportedly activate MCs via the $\mathrm{S}_{1} \mathrm{P}_{2}$, MRGPRB2, $\mathrm{P}_{2} \mathrm{Y}_{14}, \mathrm{C} 5 \mathrm{a}, \mathrm{H}_{3}, \mathrm{DP} 2$, and EP3 receptors, respectively [6]. In this study, these agonists had little effect on $\mathrm{MC}$ degranulation alone, with only $\mathrm{PGE}_{2}$ causing a strong degranulation response when co-stimulated with ATP. Since ATP is known to promote PG production in various tissues [23,24], this finding may help understand the physiological functions of MCs.

The biological effects of $\mathrm{PGE}_{2}$ are mediated by four different receptor subtypes, EP1, EP2, EP3, and EP4Rs [25]. EP3R has been well characterized as the site of action via which $\mathrm{PGE}_{2}$ stimulates MC degranulation alone or in the presence of $\mathrm{Ag}[9,10,22]$. In this study, pharmacological investigation using receptor subtype selective agonists and antagonists indicated that the costimulatory effects of $\mathrm{PGE}_{2}$ and ATP on degranulation were also mediated by EP3R. In particular, the effect of $\mathrm{PGE}_{2}$ was inhibited by the selective EP3 antagonist ONO-AE3-208 and mimicked by the selective EP3 agonist ONO-AE-2248. Furthermore, our observation that the effect of $\mathrm{PGE}_{2}$ was abolished by the PTX-mediated inactivation of Gi-dependent signals is consistent with the fact that EP3R is the only Gi-coupled EP receptor subtype [25]. With respect to ATP receptors, we previously demonstrated that BMMCs express mRNA for the P2X1, P2X4, P2X7, P2 $\mathrm{Y}_{1}, \mathrm{P}_{2} \mathrm{Y}_{2}$ and $\mathrm{P} 2 \mathrm{Y}_{14}$ receptors [12]. Several results obtained in this study clearly suggest that the effect of ATP was mediated by P2X4R, similar to enhanced Ag-induced degranulation [12]. First, combining PGE2 with the P2 $Y_{1}$ agonist ADP, $\mathrm{P}_{2} \mathrm{Y}_{2}$ agonist UTP, and $\mathrm{P}_{2} \mathrm{Y}_{14}$ agonist UDP-glucose did not mimic the effect of ATP on degranulation. In addition, the effect of ATP and PGE 2 was affected by neither the P2 $Y_{1}$ antagonist MRS2179 nor the $\mathrm{P}_{2} \mathrm{Y}_{2}$ antagonist AR-C118925, indicating that $\mathrm{G}$ protein-coupled P2Y receptors are not involved in ATP and $\mathrm{PGE}_{2}$-induced degranulation. Moreover, degranulation induced by ATP and $\mathrm{PGE}_{2}$ was inhibited by the P2X4 antagonist 5-BDBD but not the P2X1 antagonist NF449 or P2X7 antagonist AZ10606120, and was enhanced by the P2X4R positive allosteric modulator ivermectin [26]. Finally, the degranulation induced by ATP and $\mathrm{PGE}_{2}$ was impaired in BMMCs prepared from P2X4R-deficient mice, suggesting that co-activation of Gi-coupled EP3R and ionotropic P2X4R induces MC degranulation.

Previously, we demonstrated that P2X4R stimulation promotes Ag-induced tyrosine phosphorylation signaling, providing a possible mechanism for synergistic MC degranulation in 
response to Ag and ATP [13]. However, this mechanism was not involved in the effect of ATP and $\mathrm{PGE}_{2}$ on MC degranulation, since the response to ATP and $\mathrm{PGE}_{2}$ was insensitive to the tyrosine kinase inhibitor PP2 or Syk inhibitor R406, both of which inhibited the synergistic degranulation induced by Ag and ATP. Furthermore, ATP, $\mathrm{PGE}_{2}$, and their combination failed to induce Syk phosphorylation. It has been demonstrated that stimulating EP3R with $\mathrm{PGE}_{2}$ in BMMCs induces G $\beta \gamma$-mediated PLC $\gamma$ and PI3K $\gamma$ activation, increased phosphorylation of Akt (a kinase downstream of PI3K), and functionally promotes $\mathrm{Ca}^{2+}$ influx $[9,11]$. In this study, degranulation induced by ATP and $\mathrm{PGE}_{2}$ was inhibited by the non-selective PI3K inhibitor LY294002 and PI3K $\gamma$ selective inhibitor AS605240; however, ATP did not enhance $\mathrm{PGE}_{2}$-induced Akt phosphorylation but rather decreased it slightly. Although ATP itself slightly stimulates Akt phosphorylation, this effect is unchanged in P2X4R KO mice [13], suggesting that ATP-induced Akt phosphorylation is mediated by a receptor other than P2X4R and that P2X4R stimulation does not affect $\mathrm{G} \beta \gamma$-mediated PI3K $\gamma$ activation. These results suggest that PI3K $\gamma$ activation is necessary for ATP and $\mathrm{PGE}_{2}$-induced degranulation but that the downstream mechanism differs to that described for the combination of $\mathrm{Ag}$ and $\mathrm{PGE}_{2}[9,11]$.

In the $\mathrm{Ca}^{2+}$ assay, we observed an enhanced $\left[\mathrm{Ca}^{2+}\right]$ i response to ATP and $\mathrm{PGE}_{2}$ that was abrogated in BMMCs obtained from P2X4R KO mice and partly suppressed by inhibiting PI3K $\gamma$ with AC605240. Assuming that $\mathrm{Ca}^{2+}$ influx through P2X4R is crucial for degranulation in response to ATP and $\mathrm{PGE}_{2}$, two potential mechanisms could be inferred. First, since it has been reported that P2X4R channel activity is enhanced by membrane PI(3,4,5)P3 accumulation [27], EP3R-mediated PI3K $\gamma$ activation may cause PI $(3,4,5) \mathrm{P} 3$ accumulation which in turn promotes P2X4R-mediated $\mathrm{Ca}^{2+}$ influx. Second, MCs have been reported to possess functional $G$ protein-coupled inwardly-rectifying $\mathrm{K}^{+}$channel (GIRK), a G $\beta \gamma$-gated $\mathrm{K}^{+}$channels [28]; therefore, EP3R activation may open these channels, hyperpolarizing the membrane and increasing in driving force of $\mathrm{Ca}^{2+}$ influx [29] through the P2X4 receptor. Similar methods of regulation have been demonstrated in Ag-induced MC activation, where $\mathrm{Ca}^{2+}$-activated $\mathrm{K}^{+}$ channels play a critical role in facilitating $\mathrm{Ca}^{2+}$ influx via store-operated $\mathrm{Ca}^{2+}$ channels [30]. Further research using electrophysiological analysis is required to explore the precise mechanism of crosstalk between EP3 and P2X4R signaling.

Local $\mathrm{PGE}_{2}$ administration has been reported to enhance vascular permeability by directly activating MCs via EP3R activation [22]. In this study, a similar effect of $\mathrm{PGE}_{2}$ was reproduced in WT mice but not MC-deficient Kit ${ }^{W s h} /$ Wsh mice, while the $\mathrm{PGE}_{2}$-induced increase in vascular permeability was shown to be significantly attenuated in P2X4R-deficient mice. These results indicate that ATP positively controls the responsiveness of MCs to $\mathrm{PGE}_{2}$ via P2X4R in vivo. Since both ATP and $\mathrm{PGE}_{2}$ are extracellular mediators that accumulate in damaged or inflamed tissues, the response described here may help to understand the role of MCs in Ag-independent hypersensitivity [14].

Recent accumulating evidence suggest that P2X4R signal is involved in several inflammatory diseases, including neuropathic pain induced by nerve injury [31], joint inflammation in rheumatoid arthritis [32], rejection to transplanted tissue [33], and allergic airway inflammation [34]. The present study focused on the MC degranulation response, an early event in MC activation. As mentioned earlier, MCs can produce wide variety of cytokines [16], which affect chronic responses related to inflammatory diseases. It is therefore important to examine whether P2X4R signaling would affect the MC cytokine production.

In summary, this study demonstrated that co-stimulating MCs with ATP and $\mathrm{PGE}_{2}$ synergistically induces degranulation via ionotropic P2X4R and Gi-coupled EP3R, respectively (Figure 8). Moreover, this reaction is independent of the tyrosine kinase cascade, which plays a major role in the Ag-induced response, and is likely to involve enhanced $\mathrm{Ca}^{2+}$ influx in a manner dependent on EP3R-mediated PI3K activation. Previously, we reported that ATP also promotes Ag-induced allergic reactions via P2X4R activation; therefore, P2X4R signaling is suggested to act as an enhancer for both Ag-dependent and -independent MC activation. Taken together, targeting the ionotropic P2X4R may be a novel strategy for controlling allergic reactions. 


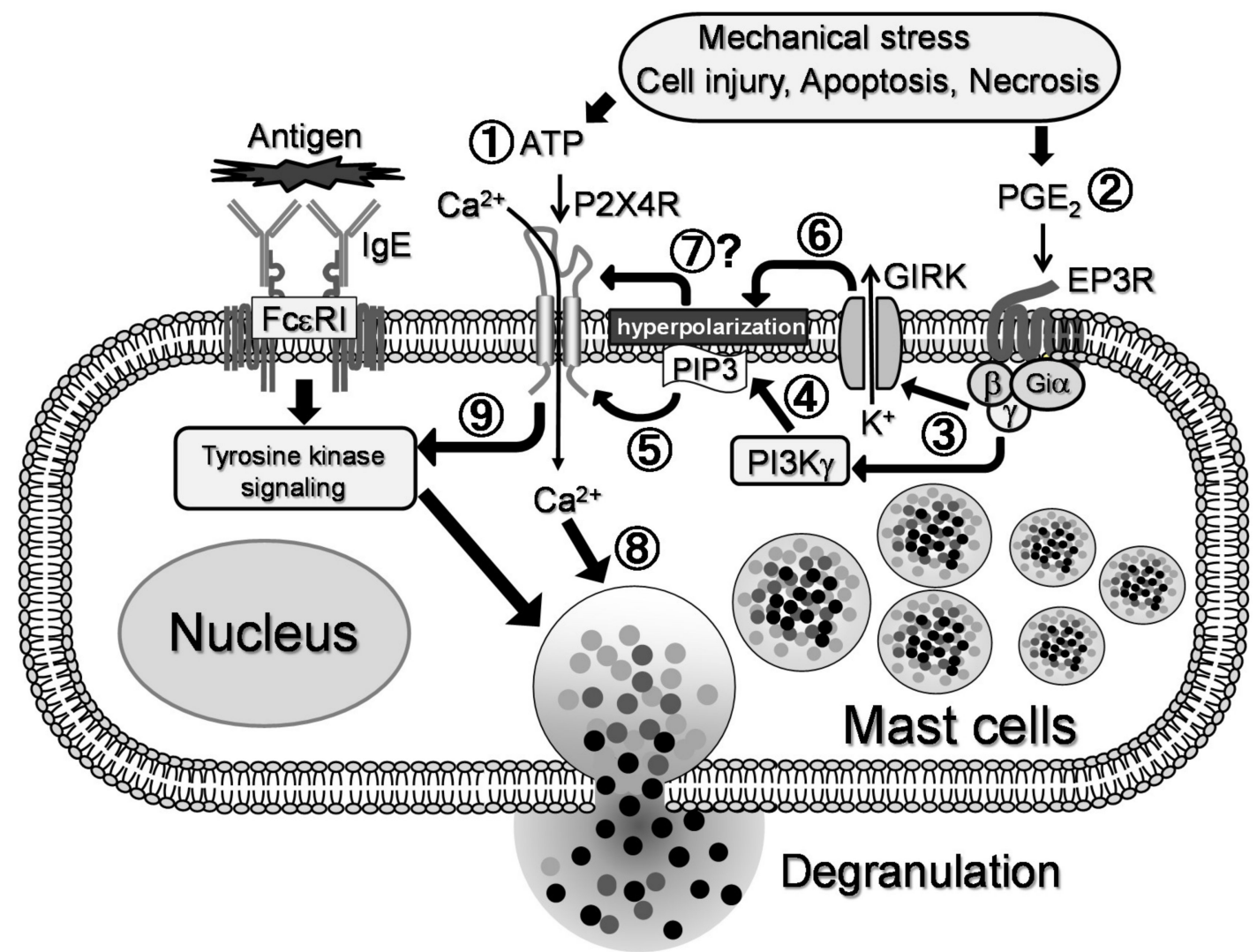

Figure 8. Proposed mechanism of interaction between P2X4 receptor (P2X4R) and EP3 receptor (EP3R) signals for the synergistic degranulation in mast cells(MCs). Extracellular ATP released from damaged cells stimulates MC P2X4R (1), leading to $\mathrm{Ca}^{2+}$ influx. Such conditions are accompanied by an inflammation with increased production of prostaglandin $(\mathrm{PG}) \mathrm{E}_{2}$. In $\mathrm{MCs}, \mathrm{PGE}_{2}$ stimulates Gi-coupled EP3R (2), leading to activation of phosphoinositide 3-kinase (PI3K) $\gamma$ and G protein-coupled inwardly-rectifying $\mathrm{K}^{+}$channel (GIRK) via $\beta \gamma$-complex of the $\mathrm{G}$ protein (3). Activation of PI3K $\gamma$ increases phosphoinositide-3,4,5-trisphosphate (PIP3) levels in plasma membrane (4), thereby promoting P2X4R channel activity (5). GIRK activation may cause hyperpolarization of the membrane potential (6), which would increase the driving force of $\mathrm{Ca}^{2+}$ inflow through P2X4R (7). These interactions between P2X4R and EP3R signals lead to the observed synergy in MC degranulation (8). P2X4R signal also promotes IgE-dependent tyrosine kinase-mediated signals to induce facilitated degranulation, as described previously (9) [12].

\section{Materials and Methods}

\subsection{Materials}

UTP, ATP, ADP, $\mathrm{PGE}_{1}, \mathrm{PGE}_{2}$, 2,4-dinitrophenyl human serum albumin (DNP-HSA), anti-DNP IgE (clone SPE-7), $p$-nitrophenyl $N$-acetyl- $\beta$-d-glucosaminide, and the GenElute Mammalian Total RNA miniprep kit were obtained from Sigma-Aldrich (Tokyo, Japan). Allophycocyanin (APC)-conjugated rat anti-mouse c-Kit antibodies (clone 2B8) were obtained from BD Pharmingen (Tokyo, Japan). Phycoerythrin (PE)-conjugated mouse anti-mouse FceRI $\alpha$ antibodies (clone MAR-1) were obtained from eBioscience (San Diego, CA, USA). Recombinant mouse interleukin (IL)-3 and recombinant mouse SCF were obtained from Peprotech (London, UK). MRS2179, AR-C118925, NF449, AZ10606120, 5-BDBD, Ivermectin, PP2, LY303511, LY294002, Triciribine, and AS605240 were obtained from Tocris Bioscience (Bristol, UK). R406 was obtained from Cayman Chemical (Michigan, USA). Fura-2-acetoxymethylester (AM) and PTX were obtained from Wako (Osaka, Japan). Anti-phospho-Syk, anti-Syk, anti-phospho-ERK1/2, anti-ERK1/2, anti-phospho-Akt, and anti-Akt antibodies were obtained from Cell Signaling Technology (Danvers, MA, USA). ONO-DI-004 (selective EP1 agonist), 
ONO-AE1-259-01 (selective EP2 agonist), ONO-AE-248 (selective EP3 agonist), and ONO-AE1-329 (selective EP4 agonist) were obtained from ONO Pharmaceuticals (Osaka, Japan). All other chemicals were of reagent-grade or the highest quality available.

\subsection{Animals}

P2X4R-deficient mice were generated by Dr. Yamamoto (University of Tokyo), as described previously [35]. C57BL/6 and $\mathrm{Kit}^{\mathrm{Wsh} / \mathrm{Wsh}}$ mice were purchased from SLC Japan (Hamamatsu, Japan) and RIKEN (Ibaraki, Japan), respectively. All mice were maintained under specific pathogen-free conditions at the animal facility of Takasaki University of Health and Welfare. All experiments were performed in accordance with the regulations of the Animal Research Committee of Takasaki University of Health and Welfare.(Approval number: 1813, 1 April, 2018)

\subsection{Cell Culture}

BMMCs were established using bone marrow from C57BL/6 mice, as described previously [36]. Briefly, bone marrow cells were collected from the femur and cultured in RPM I1640 medium containing $10 \%$ fetal bovine serum, 100 units $/ \mathrm{mL}$ penicillin, $100 \mu \mathrm{g} / \mathrm{mL}$ streptomycin, and $10 \mathrm{ng} / \mathrm{mL}$ recombinant IL-3. After 2 weeks, the cells were cultured with $10 \mathrm{ng} / \mathrm{mL}$ of recombinant SCF for $4-6$ weeks. After these treatments, almost all (>95\%) cells displayed an MC phenotype, as indicated by CD117 (c-Kit) and FceRI expression measured using a FACSCant II flow cytometer (BD Biosciences, Tokyo, Japan).

\subsection{Degranulation Assay}

Degranulation was evaluated by measuring $\beta$-hexosaminidase release, as described previously [36]. BMMCs were sensitized with $50 \mathrm{ng} / \mathrm{mL}$ anti-DNP IgE overnight in RPMI 1640 growth medium. Cells were washed twice with phosphate buffered saline (PBS), suspended in Krebs-Ringer-HEPES (KRH) buffer (130 mM NaCl, $4.7 \mathrm{mM} \mathrm{KCl}, 4.0 \mathrm{mM} \mathrm{NaHCO}, 1.2 \mathrm{mM} \mathrm{KH}_{2} \mathrm{PO}_{4}, 1.2 \mathrm{mM} \mathrm{MgSO}_{4}, 1.8 \mathrm{mM} \mathrm{CaCl}_{2}$, $11.5 \mathrm{mM}$ glucose) and $10 \mathrm{mM}$ HEPES (pH 7.4) containing $0.1 \%$ bovine serum albumin (BSA), and then stimulated under various conditions for $5 \mathrm{~min}$ at $37^{\circ} \mathrm{C}$. Reactions were terminated by placing the cells on ice and centrifuging them. Supernatants were collected and the cell pellets were lysed in $1 \%$ Triton $\mathrm{X}-100$. The supernatant and cell lysate were incubated with an equal volume of $1 \mathrm{mM}$ p-nitrophenyl $\mathrm{N}$-acetyl- $\beta$-D-glucosaminide dissolved in citrate buffer $(\mathrm{pH} 4.5)$ in a 96 -well plate at $37^{\circ} \mathrm{C}$ for $30 \mathrm{~min}$. $\mathrm{Na}_{2} \mathrm{CO}_{3} / \mathrm{NaHCO}_{3}$ buffer ( $\mathrm{pH}$ 10.4) was then added and the absorbance was measured at $405 / 655 \mathrm{~nm}$.

\section{5. $\left[\mathrm{Ca}^{2+}\right]$ i Measurement}

Cells were collected and washed twice with KRH containing 0.1 \% BSA, suspended in KRH-BSA buffer, and treated with $1 \mu \mathrm{M}$ Fura-2 $\mathrm{AM}$ at $37^{\circ} \mathrm{C}$ for $20 \mathrm{~min}$. The Fura-2-loaded cells were washed twice with KRH-BSA buffer and adjusted to $1-2 \times 10^{5}$ cells $/ \mathrm{mL}$. Changes in Fura-2 fluorescence were measured as described previously [36].

\subsection{Western Blot}

Cells were collected, washed with PBS, and resuspended in KRH. The reaction was performed in KRH buffer and terminated by adding $4 \times$ sample buffer. The lysate was separated by $10 \%$ sodium dodecyl sulfate polyacrylamide gel electrophoresis (SDS-PAGE) and transferred to Immobilon-P polyvinylidene fluoride (PVDF) membranes. The PVDF membranes were blocked with 5\% BSA-TBST for $1 \mathrm{~h}$ at room temperature, exposed to primary antibodies overnight at $4{ }^{\circ} \mathrm{C}$, and secondary antibodies for $2 \mathrm{~h}$ at room temperature. Antibodies were diluted as follows: anti-phospho-Syk (1:1000), anti-syk (1:1000), anti-phospho-ERK1/2 (1:1000), anti-ERK1/2 (1:1000), anti-phospho-Akt (1:1000), anti-Akt (1:1000), and horseradish peroxidase (HRP)-linked anti-rabbit IgG (1:10000). The entire western blots were shown in Supplementary Materials. 


\subsection{Quantitative RT-PCR ( $q R T-P C R)$}

Total RNA was isolated using the GenElute Mammalian Total RNA miniprep kit. First-strand cDNA was synthesized using Moloney Murine Leukemia Virus reverse transcriptase with a 6-mer random primer. qRT-PCR was performed using an SYBR green kit, as described previously [37].

\section{8. $P G E_{2}$-Induced Skin Edema}

Mice were anesthetized with isoflurane, injected intravenously with $200 \mu \mathrm{L} 0.5 \%$ Evans blue diluted in PBS, and injected intradermally in the right ear with $\mathrm{PGE}_{2}(1.5 \mathrm{nmol})$ in $20 \mu \mathrm{L}$ saline and in the left ear with a vehicle of $0.1 \%$ ethanol in saline. After $30 \mathrm{~min}$, the mice were sacrificed and their ears collected and weighed. Evans blue dye was extracted from the ears with $1 \mathrm{~mL}$ formamide at $55^{\circ} \mathrm{C}$ for $24 \mathrm{~h}$ and absorbance measured at $620 \mathrm{~nm}$. Data are expressed as $\mu \mathrm{g}$ of Evans blue per $\mathrm{mg}$ of ear.

\subsection{Statistics}

All experiments were repeated at least three times, yielding similar results. Data represent the mean \pm standard error of the mean (SEM). Statistical analyses were performed using the Student's $t$-test for two sample comparisons and one-way analysis of variance (ANOVA) with Dunnett's two-tailed test for multiple comparisons. $p$ values $<0.05$ were considered statistically significant.

Supplementary Materials: The following are available online at http://www.mdpi.com/1422-0067/20/20/5157/s1.

Author Contributions: Conceptualization, K.Y. (Kazuki Yoshida), M.I. and I.M.; Methodology, K.Y. (Kazuki Yoshida), M.I. and I.M.; Formal analysis, K.Y. (Kazuki Yoshida); Investigation, K.Y. (Kazuki Yoshida), M.T., T.N. and K.O.; Resources, K.Y. (Kimiko Yamamoto); Data curation, K.Y. (Kazuki Yoshida); Writing-Original draft preparation, K.Y. (Kazuki Yoshida); Writing—Review and editing, I.M.

Funding: This research was funded by JSPS KAKENHI, grant numbers 18K14925 to K.Y and 19K07328 to I.M., and by the The Japan Science Society, Sasakawa Scientific Research Grant to K.Y.

Conflicts of Interest: The authors declare no conflict of interest.

\section{Abbreviations}

$\begin{array}{ll}{\left[\mathrm{Ca}^{2+}\right] \mathrm{i}} & \text { Intracellular } \mathrm{Ca}^{2+} \text { concentration } \\ \mathrm{A}_{3} \mathrm{R} & \mathrm{A}_{3} \text { receptor } \\ \mathrm{Ag} & \text { Antigen } \\ \mathrm{APC} & \text { Allophycocyanin } \\ \text { BMMCs } & \text { Bone marrow-derived mast cells } \\ \text { DNP-HSA } & \text { 2,4-dinitrophenyl human serum albumin } \\ \text { EP3R } & \text { EP3 receptor } \\ \text { FcERI } & \text { High affinity IgE receptors } \\ \text { GPCR } & \text { G-protein-coupled receptors } \\ \text { IL } & \text { Interleukin } \\ \text { KRH } & \text { Krebs-Ringer-HEPES } \\ \text { MC } & \text { Mast cell } \\ \text { P2X4R } & \text { P2X4 receptor } \\ \text { PE } & \text { Phycoerythrin } \\ \text { PG } & \text { Prostaglandin } \\ \text { PI3K } & \text { Phosphoinositide 3-kinase } \\ \text { PLC } & \text { Phospholipase C } \\ \text { PTX } & \text { Pertussis toxin } \\ \text { PVDF } & \text { Immobilon-P polyvinylidene fluoride } \\ \text { qRT-PCR } & \text { Quantitative reverse transcription-polymerase chain reaction } \\ \text { S1P } & \text { Sphingosine-1-phosphate } \\ \text { SDS-PAGE } & \text { Sodium dodecyl sulfate polyacrylamide gel electrophoresis } \\ & \end{array}$




\section{References}

1. Metcalfe, D.D.; Baram, D.; Mekori, Y. Mast cells. Pharmacol. Rev. 1997, 77, 1033-1079. [CrossRef] [PubMed]

2. Da Silva, E.Z.M.; Jamur, M.C.; Oliver, C. Mast cell function: A new vision of an old cell. J. Histochem. Cytochem. 2014, 62, 698-738. [CrossRef] [PubMed]

3. Metcalfe, D.D.; Peavy, R.D.; Gilfillan, A.M. Mechanisms of mast cell signaling in anaphylaxis. J. Allergy Clin. Immunol. 2009, 124, 639-646. [CrossRef] [PubMed]

4. Metzger, H. The receptor with high affinity for IgE. Immunol. Rev. 1992, 125, 37-48. [CrossRef]

5. Gilfillan, A.M.; Tkaczyk, C. Integrated signalling pathways for mast-cell activation. Nat. Rev. Immunol. 2006, 6, 218-230. [CrossRef]

6. Kuehn, H.S.; Gilfillan, A.M. G protein-coupled receptors and the modification of FceRI-mediated mast cell activation. Immunol. Lett. 2007, 113, 59-69. [CrossRef]

7. Moncada, S.; Ferreira, S.; Vane, J. Prostaglandins, aspirin-like drugs and the oedema of inflammation. Nature 1973, 246, 217-219. [CrossRef]

8. Borea, P.A.; Gessi, S.; Merighi, S.; Varani, K. Adenosine as a multi-signalling guardian angel in human diseases: When, where and how does it exert its protective Effects? Trends Pharmacol. Sci. 2016, 37, 419-434. [CrossRef]

9. Kuehn, H.S.; Beaven, M.A.; Ma, H.-T.; Kim, M.-S.; Metcalfe, D.D.; Gilfillan, A.M. Synergistic activation of phospholipases $C \gamma$ and $C \beta$ : A novel mechanism for PI3K-independent enhancement of FceRI-induced mast cell mediator release. Cell. Signal. 2008, 20, 625-636. [CrossRef]

10. Kuehn, H.S.; Jung, M.-Y.; Beaven, M.A.; Metcalfe, D.D.; Gilfillan, A.M. Prostaglandin E 2 activates and utilizes mTORC2 as a central signaling locus for the regulation of mast cell chemotaxis and mediator release. J. Biol. Chem. 2011, 286, 391-402. [CrossRef]

11. Laffargue, M.; Calvez, R.; Finan, P.; Trifilieff, A.; Barbier, M.; Altruda, F.; Hirsch, E.; Wymann, M.P. Phosphoinositide 3-kinase $\gamma$ is an essential amplifier of mast cell function. Immunity 2002, 16, 441-451. [CrossRef]

12. Yoshida, K.; Ito, M.; Matsuoka, I. Divergent regulatory roles of extracellular ATP in the degranulation response of mouse bone marrow-derived mast cells. Int. Immunopharmacol. 2017, 43, 99-107. [CrossRef] [PubMed]

13. Yoshida, K.; Ito, M.; Yamamoto, K.; Koizumi, S.; Tanaka, S.; Furuta, K.; Matsuoka, I. Extracellular ATP augments antigen-induced murine mast cell degranulation and allergic responses via P2X4 receptor activation. J. Immunol. 2019. submitted for publication.

14. Redegeld, F.A.; Yu, Y.; Kumari, S.; Charles, N.; Blank, U. Non-IgE mediated mast cell activation. Immunol. Rev. 2018, 282, 87-113. [CrossRef] [PubMed]

15. Fitz, J.G. Regulation of cellular ATP release. Trans. Am. Clin. Climatol. Assoc. 2007, 118, 199-208.

16. Gallenga, C.; Pandolfi, F.; Caraffa, A.; Ronconi, G.; Toniato, E.; Martinotti, S.; Conti, P. Interleukin-1 family cytokines and mast cells: activation and inhibition. J. Biol. Regul. Homeost. Agents 2019, 33, 1-6.

17. Caraffa, A.; Gallenga, C.E.; Kritas, S.K.; Ronconi, G.; Conti, P. Impact of mast cells in systemic lupus erythematosus: can inflammation be inhibited? J. Biol. Regul. Homeost. Agents 2019, 33, 669-673.

18. Antonopulos, D.; Tsilioni, I.; Balatsos, N.A.A.; Gourgoulianis, K.I.; Theoharides, T.C. The mast cell-Neurofibromatosis connection. J. Biol. Regul. Homeost. Agents 2019, 33, 657-659.

19. Lazarowski, E.R. Vesicular and conductive mechanisms of nucleotide release. Purinergic. Signal 2012, 8, 359-373. [CrossRef]

20. Dosch, M.; Gerber, J.; Jebbawi, F.; Beldi, G. Mechanisms of ATP Release by inflammatory cells. Int. J. Mol. Sci. 2018, 19, 1222. [CrossRef]

21. Burnstock, G. Purinergic signalling: Therapeutic developments. Front. Pharmacol. 2017, 8, 661. [CrossRef] [PubMed]

22. Morimoto, K.; Shirata, N.; Taketomi, Y.; Tsuchiya, S.; Segi-Nishida, E.; Inazumi, T.; Kabashima, K.; Tanaka, S.; Murakami, M.; Narumiya, S.; et al. Prostaglandin $\mathrm{E}_{2}-\mathrm{EP} 3$ signaling induces inflammatory swelling by mast cell activation. J. Immunol. 2014, 192, 1130-1137. [CrossRef] [PubMed]

23. Needleman, P.; Minkes, M.S.; Douglas, J.R. Stimulation of prostaglandin biosynthesis by adenine nucleotides: Profile of prostaglandin release by perfused organs. Circ. Res. 1974, 34, 455-460. [CrossRef] [PubMed] 
24. Loredo, G.A.; Benton, H.P. ATP and UTP activate calcium-mobilizing P2U-like receptors and act synergistically with interleukin-1 to stimulate prostaglandin $\mathrm{E}_{2}$ release from human rheumatoid synovial cells. Arthritis Rheum. 1998, 41, 246-255. [CrossRef]

25. Sugimoto, Y.; Narumiya, S. Prostaglandin E receptors. J. Biol. Chem. 2007, 282, 11613-11617. [CrossRef]

26. Khakh, B.S.; Proctor, W.R.; Dunwiddie, T.V.; Labarca, C.; Lester, H.A. Allosteric control of gating and kinetics at P2X 4 receptor channels. J. Neurosci. 1999, 19, 7289-7299. [CrossRef]

27. Bernier, L.-P.; Ase, A.R.; Chevallier, S.; Blais, D.; Zhao, Q.; Boue-Grabot, E.; Logothetis, D.; Seguela, P. Phosphoinositides regulate P2X4 ATP-gated channels through direct interactions. J. Neurosci. 2008, 28, 12938-12945. [CrossRef]

28. Qian, Y.X.; McCloskey, M.A. Activation of mast cell $\mathrm{K}^{+}$channels through multiple $\mathrm{G}$ protein-linked receptors. Proc. Natl. Acad. Sci. USA 1993, 90, 7844-7848. [CrossRef]

29. Ashmole, I.; Bradding, P. Ion channels regulating mast cell biology. Clin. Exp. Allergy 2013, 43, 491-502. [CrossRef]

30. Shumilina, E.; Lam, R.S.; Wölbing, F.; Matzner, N.; Zemtsova, I.M.; Sobiesiak, M.; Mahmud, H.; Sausbier, U.; Biedermann, T.; Ruth, P.; et al. Blunted IgE-mediated activation of mast cells in mice lacking the $\mathrm{Ca}^{2+}$ -Activated $\mathrm{K}^{+}$channel K Ca 3.1. J. Immunol. 2008, 180, 8040-8047. [CrossRef]

31. Tsuda, M.; Shigemoto-Mogami, Y.; Koizumi, S.; Mizokoshi, A.; Kohsaka, S.; Salter, M.W.; Inoue, K. P2X4 receptors induced in spinal microglia gate tactile allodynia after nerve injury. Nature 2003, 424, 778-783. [CrossRef] [PubMed]

32. Li, F.; Guo, N.; Ma, Y.; Ning, B.; Wang, Y.; Kou, L. Inhibition of P2X4 suppresses joint inflammation and damage in collagen-induced arthritis. Inflammation 2014, 37, 146-153. [CrossRef] [PubMed]

33. Ledderose, C.; Fakhari, M.; Lederer, J.A.; Robson, S.C.; Visner, G.A.; Junger, W.G.; Liu, K.; Kondo, Y.; Slubowski, C.J.; Dertnig, T.; et al. Purinergic P2X4 receptors and mitochondrial ATP production regulate T cell migration. J. Clin. Invest. 2018, 128, 3583-3594. [CrossRef] [PubMed]

34. Zech, A.; Wiesler, B.; Ayata, C.K.; Schlaich, T.; Dürk, T.; Hoßfeld, M.; Ehrat, N.; Cicko, S.; Idzko, M.; Zech, A.; et al. P2rx4 deficiency in mice alleviates allergen-induced airway inflammation. Oncotarget 2016, 7, 80288-80297. [CrossRef] [PubMed]

35. Yamamoto, K.; Sokabe, T.; Matsumoto, T.; Yoshimura, K.; Shibata, M.; Ohura, N.; Fukuda, T.; Sato, T.; Sekine, K.; Kato, S.; et al. Impaired flow-dependent control of vascular tone and remodeling in P2X4-deficient mice. Nat. Med. 2006, 12, 133-137. [CrossRef]

36. Yoshida, K.; Ito, M.; Matsuoka, I. P2X7 receptor antagonist activity of the anti-allergic agent oxatomide. Eur. J. Pharmacol. 2015, 767, 41-51. [CrossRef]

37. Ito, M.; Matsuoka, I. Inhibition of $\mathrm{P}_{2} \mathrm{Y}_{6}$ receptor-mediated phospholipase $\mathrm{C}$ activation and $\mathrm{Ca}^{2+}$ signalling by prostaglandin $\mathrm{E}_{2}$ in J774 murine macrophages. Eur. J. Pharmacol. 2015, 749, 124-132. [CrossRef] 